胎児腸管径は在胎週数の進行とともに增加し, 胎児推定体重と も密接な関連を示し発育の指標之考えられた。また，腸管内容は 胎児の発育とともにその echogenicity を增し, 胎児消化器系機 能を反映することが推察された。

58）いわゆるケロイドの臨床症状に関する統計学的 検索およびアミノ酸含有軟亮の臨床医学的研究

形成外科 吉田秀也 - 白井洋司 - 文入正敏

いわゆるケロイドについて過去さまざまな分類と，それに対す る治療が検討されているが, 痛みや痒みなどの臨床症状に関して は，その統計的な研究はなされていない，われわれは今回当科外 来に来院し, アミノ酸含有軟高の外用治療を行った患者を対象と し，痛みや痒及の発現頻度および，その治療効果につき統計的検 討を加えたので報告する。

59）自家骨頭を利用する臼蓋形成術を併用した全人 工股関節置換術の経験

$\begin{array}{lll}\text { 第一病院整形外科 } & \text { 南 和文・中川 俊 - 千葉由雄 } \\ & \text { 藤原 淳・清水 学・吉川 昇 } \\ & \text { 小林明雄 }\end{array}$

国立熱海病院 加藤和義

(はじめに) 先天性股関節脱臼や亜脱臼に起因する二次性変形 性股関節症は著明な臼蓋形成不全を伴っていることが多い。この

\section{展示発 表}

P-1）長期高血糖の不完全脳虚血における脳浮腫お よび脳代謝に及ぼす影響

\section{内科第 2 木村俊介・片山泰朗・稲村憲治 柏木史彦・大坪孝一・赫 彰郎}

〔目的]長期高血糖状態が脑虚血の進展に及ぼす影響について 検討を行った。

〔方法〕動物は高血圧自然発生ラット(SHR)を使用した。高血 糖状態は streptozotocin (STZ) の投与により作成した。すなわ ち, 8 週齢の SHR に $30 \mathrm{mg} / \mathrm{kg} \mathrm{STZ}$ を腹腔内投与して 5 週間飼 育した (高血糖群), 対照群 (正常血糖群) は, vehicle 索同量投 与した. 13 週齢にて高血糖群㧍よび正常血糖群を用いて両側総頚 動脈結毞法により脳虚血を作成し，3時間虚血後に脳含水量およ び脳代謝諸量を測定した。 また、コントロール群(非虚血群) と して，高血桾群，正常血桾群を用いて同様に検討した。

〔結果〕コントロールの検討にて脳含水量では, 高血糖群におい て低値を認めたが, 脳代謝諸量では差異を認めなかった。脳虚血 の検討では, 高血糖群は正常血糖群に比へて脳含水量において有 意な低値を認めたが, それぞれのコントロール群からの增加率に 差異を認めなかった。脳代謝諸量では, 両群ともコントロール群
よらな症例に対して全人工股関節置換術を施行するのは困難で あるが，われわれは切除した骨頭を移植する臼蓋形成術を併用 し，良好な結果が得られたので報告する。

(対象と方法)昭和 62 年 5 月より現在むでに 9 例, 13 関節, そ の5ち両側例は 4 例で全例女性である。手術時年龄は 39 歳 8 力 月より 68 歳 10 力月, 平均年龄は 54.3 歳である. 人工関節は八リ ス式プレコートタイブを使用した。全例手術時に摘出した大腿骨 頭を成形し A-O 螺子にて固定し白蓋を作成した。平均経過観察 期間は 31 力月一 3 力月, 平均 16 力月である。

(結果) 日整会股関節判定基準の平均は術前 49.9 点, 術後 87.4 点と著明に改善している。シャープ角の平均は術前 50.8 度, 術後 31.5 度であり, CE 角の平均は術前 2.7 度, 術後 59.5 度と十分な 求心位がとれている。骨頭引き下げ距離は 15 56 mm, 平均 27.4 $\mathrm{mm}$ であるが，このための神経血管障害はない。

(考察) 臼蓋形成不全例に対して自家骨頭を利用した臼蓋形成 術を併用すると，より原臼に近い位置にンケットを作成すること が可能になり, 安定性があり, 患肢の短縮も改善できバイオメカ ニクス的にも効果的な全人工股関節置換術が行える.

に比べて Lactate の增加, ATP の低下を認めたが, Pyruvate は 差異がなかった。 また, 脳虚血における, 高血糖群および正常血 糖群の両群間には, これらの脳代謝諸量の差異は認めなかった。

結語：長期高血糖状態は, 虚血早期に掞いて脳虚血の進展に影 響を及ぼしていないことが示唆された。

P-2）急性発症した歩行障害を主訴とした第 3 脳室 にみられた巨大なくも膜霖胞の 1 乳児例

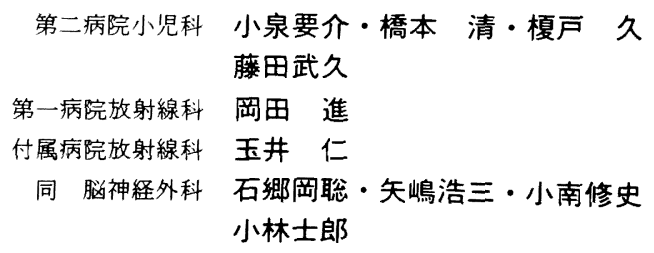

くも膜虽胞は比較的頻度の高い先天性異常であり，CT の普及 により発見率が著しく増加したが, CTのみでは解剖学的に全体 像を把握しにくい.今回われわれは MRI, 特にその矢状断面像が 診断に有用であったくも膜妻胞の 1 乳児を経験したので報告す 
る.

症例は 1 歳 2 力月男児. 数日来急に立たなくなったことを主訴 として整形外科を受診し，整形外科的には異常なしといわれた が, 症状改善しないため小児科を紹介された。初診時頭用の払大 ( +3SD), 両側腱反射の六進をみとめたが、脳神経麻瘏, 知覚障 害, 眼振などはみられなかった.CT にて両側側脳室の高度の払大 とその周囲の低吸収像，第 3 脳室の扗大をみとめたが，第 4 脳室 の抎大はなく, 中脳水道の閉塞が疑われた. MRIの矢状断にて, 中脳水道の閉塞はなく, fornix の上方への举上を伴 5 第 3 脳室の 高度の扗大，モンロー孔の開大をみとめ，下垂体茥の前方への圧 排, トルコ鞍の払大, 橋前槽, 脚間槽の払大をみとめ, 冠状断で は第 3 脳室から脳幹に及ぶ㵦液と同じ信号域がみられた。水平断 では脳幹部は，上部の舞槽の扗大と視索の前方への王迫がみられ た. 以上の所見から第 3 脳室に及ぶ鞍上部くも膜衰胞と脳槽系之 の境界は不明であった。

脳外科にて，緊急にV.P シャントを行ったあと，衰胞一脳室 一腹腔シャント術を行った際, 組織学的に第 3 脳室のくも膜震胞 であることが確認された。

\section{P-3）めまいにて発症した後大脳動脈空形成の 1 例}

\section{多摩永山病院脳神経外科 野手洋治・志村俊郎・粟屋 栄 村山享一}

\section{付属病院脳神経外科 中沢省三}

患者： 52 歳，女性，主訴：頭痛，めまいおよび立ちくらみ。家 族歴および既応歴：特になし。

現病歴：1990 年 3 月 27 日.引っ越しの準備中, 頭痛およびめま いが出現。夜間には立ちくらみも出現した。 その後症状の改善が みられないため 3 月 30 日当科を受診し，椎骨脳底動脈系の循環 異常が疑われ入院となった。

入院時：血圧 $154 / 80 \mathrm{mmHg}$, 脈拍 $78 / \mathrm{min}$, 整. 神経学的には 主訴以外は明らかな異常はみられず，椎骨脳底動脈循環不全症お よびそれによる頭痛と診断した。六時のCTスキャンでは明ら かな異常は認められなかったが, 椎骨動脈撮影で，左後大脳動脈 近位部に空形成が認められた。

脳血管の走行異常のひとつである空形成の報告例は少なくな く, 椎骨動脈, 脳底動脈, 内頝動脈, 前大脳動脈および中大脳動 脈なとの症例が報告され，その発生機序についても検討が行われ ているが, 後大脳動脈の空形成の報告例はきわめてまれであるの で，文献的考察を加え報告する。

\section{P-4）老年者脳に見られる老人斑形成機構の研究} 一第 1 報 若年者と老年者脳のグリコサミノ グリカンの比較一

$$
\begin{array}{cl}
\text { 老人病研究所 } & \text { 清水 - - 横田 隆 - 枝川聖子 } \\
& \text { 片山博徳・小山美弥・大網 弘 }
\end{array}
$$

目的：高齢者の脳機能が低下する原因を解明するために脳内 蓄積フルミニウムと神経細胞の形態変化との関係について第 57 回総会に報告した。今回はアミロイド（老人斑）の沈着原因が， 脳内クリコサミノクリカン $(\mathrm{GAG})$ の成分との関連が予想された ので若年者脳と比較検討を行い，若千の知見を得たので報告す
る.

材料および方法：ホルマリン固定後の病変のない大脳を用い た. 高齢者は 75 歳以上 5 例, 対照として 45 歳以下 5 例を用いた。 材料は右前頭葉, 右海馬傍回より採取した. GAGの分析は組織を 蛋白分解醅素で消化抽出した抽出夜を泳動し, 得られた分画を $677 \mathrm{~nm}$ で計測した。 また, 同様の組織材料をパラフィン標本とし 形態学的検討も併せ行った。

結果：GAGの成分の分析では若年者例では右前頭葉にヒフル ロン酸(HA)が，右海馬傍回ではデルマタン硫酸が多く認められ た。高齢者例では右前頭葉ではHA が，右海馬傍回では HA, コ ンドロイチン硫酸 (Chs) が増量する傾向を認めた。

まとめ：老人斑の大部分はアミロイド蛋白とされており，正常 者でも産成されているが老人脳に沈着する機構は不明である。こ の蛋白の沈着部位が GAGの多い間質であることからアミロイ ド沈着部には GAGの存在が予想され測定した結果, 若年者脳に はHAのみが高㱓者例 HA とChs が多く認められた. GAG の種 類が高齢者で変動するといらことは興味ある知見であり, 今後こ の点についての検索が望まれる。

\section{P-5）メチオニン大量投与の脳・血管系に及ぼす影 響}

\section{老人病研究所 小山美弥・清水 一・枝川聖子 片山博徳・小山潤三・中島信治} 大網弘

〔目的〕ホモシスティン (Hcy) の血管・神経系に対しての障害 作用は上くしられている.今回われわれは, Hcyを中間代謝物の 一つとするメチオニンを, ウサギに 2 力月間経口投与し, 脳を含 めた血管系にどの様な影響を及ぼすか病理学的に検索したので 報告する。

〔方法〕動物はニュージーランドホワイトウサギ（ふ・3 kg） 8 羽を使用した、コントロール群 ( $\mathrm{C}$ 群)，メチオニン群 (M 群) 各 4 羽ずつに分け, C 群は普通食, M 群は $3 \%$ ×チオンン食で各々 7 週まで飼育し，ついで両群の飼料に $1 \%$ コレステロールを添加 し 15 週まで飼育した。ネンブタール麻酔下で灌流固定し各主要 臟器について病理学的検索を行った。 また, 飼育中, 血漿 Hcy 值 を数回測定した。

〔結果〕 1) 血漿 Hcy 平均値は C 群で $14.8 \mathrm{nmol} / \mathrm{ml}, \mathrm{M}$ 群で $294.5 \mathrm{nmol} / \mathrm{m} l$ と約 22 倍の増加が起こっていた.2）光顕所見 (1)大動脈岈状硬化は C 群では初期変化にとどまり $\mathrm{M}$ 群で強く認 められた。 (2)心臓冠動脈坫状硬化, stenosis ともM群で顕著で あった. M 群では心筋の edema, fibrosisなどがみられた. (3)脑 では C 群は変化なし，M群では神経細胞の膨化・萎縮・変性脱落 や神経細胞近位へのリンパ球浸潤，白質の spongiosisなどの変 化が著明であった，3）走査電顕所見：C群では血管内皮の変化 は軽度であった、M 群では血管内皮の剝離, 膠原線維の露出, 血 小板の固着などが認められた。 
P-6）脳腫瘍組織における superoxide dismutase 治性一electron spin resonance 法による測 定の試み一

\section{付属病院脳神経外科 池田幸穂・戸田茂樹 -中沢省三 同 研究室 佐藤純子}

目的：腫禓細胞が superoxide radical（SR）をはじめとする oxygen free radicaleを産生し，それと同時に superoxide dismutase (SOD), catalase をはじめとする free radical scanengersが低値に傾くことが報告されているが,脳腫場について論じ た報告は少ない，今回，われわれはGL glioma 細胞を用い，SR 産生能とSOD活性の測定を行ったので報告する。

方法：GL glioma cell を fisher rat の背部皮下八移植した. SR 産生能は GL glioma cell incubationすることにより検討した，SOD活性は electron spin resonance (ESR 法)，とくにDMPOによるスピン・トラップ法 を用いた。ラットは移植 3 週目に屠殺した。

結果：GL glioma cell が SR を産生しらることを NBT 法か ら証明した. GL glioma (皮下腫㾤) は正常脳に比し有意に SOD 活性の低下を認めた。

\section{P-7）姡娠 4 力月にて発症した小脳血栓症の 1 症例}

内科第 2 荒木 宏・福生吉裕・本田治久 小林陽二・赫 彰郎

妊娠 13 週目に発症した小脳血栓症の 1 例を報告した。症例は 26 歳女性で主訴は, 突然の頭痛, 眩量, 呕気, 呕吐, 右下肢の脱 力，歩行困難であった。既往歴には特記すべきことはかった。 家族歴では, 父に胃十二指腸潰湢, 脑梗塞, 母方の祖父に脑梗塞 の既往があった。現病歴としては, 本年 5 月 22 日, 午後 9 時頃, 仕事中, 突然上記主訴出現し, 勤め先である病院の処置室に運ば れ, 頭部 CT をとったが, 特に翼常は認めなかった. 翌 23 日頭部 MRIをとり, 右小脳半球の梗塞と䛦断され 25 日当院転院となっ た. 入院時血圧 $108 / 60 \mathrm{mmHg}$, 胸部所見にてラ音(一), 心雑音 (一), 腹部所見にて異常は認めなかった，ECG は正常範囲であっ た。神経学的所見にては意識清明，右の協調運動低下、軽度の失 調性歩行を認めた。深部反射の異常, 病的反射, 知賞障害, MMT の低下は認めなかった。血算, 生化学的検査にて異常は認めな かった。凝固系にては、へパプラスチンテスト $150 \%$,トロンボテ スト $150 \%$ 以, フィブリノーダン $474 \mathrm{mg} / \mathrm{d} l$ と上昇. TAT 複合 体 $4.1 \mathrm{ng} / \mathrm{m} l$, FPA $3.9 \mathrm{ng} / \mathrm{d} l, \beta$-トロンボグロブリン $168 \mathrm{ng} /$ $\mathrm{d} l$, 血小板第 $\mathrm{IV}$ 因子 $87 \mathrm{ng} / \mathrm{d} l$ と上昇, トロンビン生成六進, 血 小板放出反応穴進状態があったものと思われた。妊娠に伴5凝固 能六進を、妊娠前期よりきたし、脳梗塞を発症した症例と考えら れる.

\section{P-8）脳虚血後の超急性期における神経細胞障害 一高血糖モデルでの検討一}

\author{
内科第 2 臼田和弘・稲村憲治・木村俊介 \\ 南澤宏明・片山泰朗・赫彰郎 \\ 第一病院病理部 山田宣毒 \\ 病理第 2 浅野伍朗
}

虚血侵警に対して神経細胞は障害を受けるが，その障害の程度 は血糖に影響され、また部位によって異なることが知られてい る.今回, 高血糖下における虚血中扰よび再灌流後の超急性期の 神経細胞障害を脳の部位別に病理組織学的観察により検討した ので報告する。

方法：動物はwistar ratを用いた。高血糖は, glucoseを45 分 間静注し，血糖値を $20 \sim 25 \mu \mathrm{mol} / \mathrm{m} l$ plasma とした。脳虚血は trimethaphan camphor を静注し, 両側総䅡動脈閉塞して, さら に脱血により, 平均動脈圧を $50 \mathrm{mmHg}$ に 10 分間維持して作成 した，その後，再灌流し直後 ( 0 分)， $30 ， 60 ， 90$ および 120 分に て観察を行った.

結果：(1) Hippocampus (HP)：CA 1，CA 3 では再灌流 60 分で, Dentate gyrus(DG)では 90 分で，障害が強く見られ，120 分ではみかけ上回復が認められた. Subiculum (Sub) では 60〜120 分にかけて障害が持続して回復傾向は見られなかった。

(2) Substantia Nigra (SN)：Compacta, Reticulata 共に再灌 流直後より障害を認め, 90 分で障害が強く, 120 分でみかけ上回 復を認めた。 (3) Parietal cortex (Par)：60 分で障害が強く, 120 分でみかけ上回復が見られた。

結語：虚血侵唯に対し, 再灌流後神経細胞障害の発現, 進展が 脳局所で異なることを認めた。再灌流後神経細胞障害度は一旦增 悪するが，その後 Subを除く HP, SN, Parでみかけ上回復が見 られた. SN は再灌流直後の障害が強く, 再灌流後他の部位に比し 相対的に遅れて障害が増悪した。

P-9）高 EPA 含有脳梗塞用経管栄養剤における血 清脂質と血小板凝集能に与える影響一クリニ ミールとの封筒法による比較一

\section{内科第 2 高木信一・福生吉裕・小林陽二 赫 彰郎}

老人病研究所付属病院 瀬田健一

篠, 井総合病院内科 中沢良寿

〔目的〕多価不飽和脂肪酸であるエイコサペンタエン酸 (EPA) は血小板凝集能抑制作用拉よび抗動脈硬化作用が知られている. 今回 EPA を多く含む魚油を使用した経管栄養剤が開発され，こ れを寝たきり脳卒中患者の再発予防を目的として用い, その安全 性, 血清脂質改善作用拉よび血小板凝集抑制作用の臨床的評価を 試みた。

〔万法〕封筒法によって馒たきりの脳卒中後遗症患者 7 人に高 $\mathrm{EPA}$ 経管栄養剂（EPA 含有量 $0.69 \mathrm{~g} / 100 \mathrm{~g}$ ）を投与し, 対照栄 養剂として年齢をマッチさせた同症状患者 7 人にクリニミール を投与し, 血清脂質, 血小板凝集能, 血算, 血液生化を投与前投 与後1 月月ずつ 3 力月に渡り比較検討した。 
〔結果〕（1）動脈硬化指数は高 EPA 投与群で $4.46 \pm 2.60$ から $3.99 \pm 1.86$ に低下し，クリ二ミール投与群は $2.91 \pm 1.21$ から $2.14 \pm 0.97$ に低下し, 両群とも改善傾向がみられた。（2）中性脂 肪 $(\mathrm{mg} / \mathrm{d} l)$ は高 EPA 投与群で $123 \pm 37$ から $98 \pm 40$ と低下がみ られた。（3）過酸化脂質は両群に差はみられなかった。（4）血清 フポ蛋白はフポ A-1 $(\mathrm{mg} / \mathrm{d} l)$ で両群とも上昇を認めた。（5）丁 ポ $\mathrm{B}$ は両群とも不変であった（6）血小板凝集能は，高 $\mathrm{EPA}$ 投 与群に扣いて, コラーゲン凝集能が抑制された。 また, ADP 凝集 能も抑制傾向にあり，2 2 月目には高EPA 投与群はクリニミ ル群よりコラーゲン凝集能, ADP 凝集能とも有意に抑制した。

（7）血算, 電解質, 血清蛋白, 腎機能は両群と夕栄養剤に起因す る異常変動はみられなかった。

\section{P-10）脳卒中急性期治療薬剤の脳血管性痴呆発現 に及ほす効果の検討}

内科第 2 本田治久・福生吉裕・大村直子 村松 忠・小林陽二・赫 彰郎

栃木県・県南総合病院 漆山和夫

(目的)脳血管障害による祸呆は脳血管性痴呆と呼ばれ，実施診 療上わが国では最も多く遭遇する痴呆である。そその原因となる脳 血管障害急性期の治療としては, 主に脳浮腫に対して $10 \%$ グリセ ロール注射液が用いられ，今日では副腎皮質ステロイド剤が使用 されることはほとんどない.今回，その脳保護作用について臨床 効果が報告されている副腎皮質ステロイド㶡の使用によって，そ の後の痴呆発現に差があるかとうか検討してみたので報告する.

(方法)昭和 53 年 1 月 $~ 58$ 年の 6 年間に, 栃木県県南総合病院 内科で脳出血の診断を受け退院した患者 60 名のうち, 現時点で 生存し, かつ追跡調查が可能であった 15 名(急性期にステロイド 使用群 8 名, 非使用群 7 名) に長谷川式簡易知的機能診査スケー ル (以下 HDS) - mini-mental state 検査 (以下 MMS) ・ 国立精 神研式痴呆スクリーニングテスト(以下国精研)を実施し， $t$ 検定 により統計学的処理を実施した。

(結果) 急性期ステロイド使用群 (HDS 平均 29 点, MMS 平 均 21 点, 国精研平均 17 点) は, 非使用群 (HDS 平均 24.5 点, MMS 平均 19 点, 国精研平均 14 点) と比較し， $\mathrm{t}$ 検定では各ス ケールとも有意差は認めなかった。 なお, 同一群内で, 各スケー ル間に有意な相間を認めた $(\mathrm{p}<0.001)$.

P-11) In situ hybridization 法による aFGF と bFGF mRNA の局在の検討一特にヒト glioma を中心に一

病理第 2 安久津靖彦・間 武雄・山田裕之 浅野 伍 朗

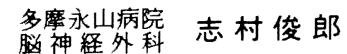 \\ 付属病院脳神経外科中沢省三 生化第 1 安 室 尚 樹・岡崎太郎}

(目的) Fibroblast growth factor, 特に acidic FGF (neparinbinding growth factor class 1 ) $と$ basic FGF (heparin-binding growth factor class 2) は，ともに腫瘍細胞や血管内皮細胞の増 殖因子であり， tumor angiogenesis との関連性が指摘されてい る。われわれは in situ hybridization 法を用いて，脳腫場内にお ける aFGF と bFGF mRNA の局在を検討し, neovasculalization と睡瘍病変の進展との関連性を観察した。

（方法）材料として当大学脳神経外科で手術をらけた脳腫竅組 織を用い, 4 \% paraformaldehyde 液で固定後, 涷結およびパラ フィン切片を作成し用いた。プローブとしては既に報告されてい る aFGF およびbFGFの nucleotide sequenceにしたがい, polymerase chain reaction (PCR) 法を用いて, first exonを 含む $203 \mathrm{bp}, 221 \mathrm{bp} の 2$ 本鎖 DNA を合成し, pGEM-3zf (一) にサプクローンしたものを鋳型にして digoxigenin-UTP 標識 RNA プロープを作成し使用した。 in situ hybridizationは, ア ルカリフォスファターセ付加抗 digoxigenin 抗体で発色し, 光学 顕徵鏡下に観察した。

(結果および結論) malignant glioma で腫場細胞および腫場内 の血管内皮細胞に $\mathrm{aFGF} と \mathrm{bFGF}$ mRNA の局在が認められた. これは malignant gliomaにおける血管新生にこれらの腫湯細胞 と血管内皮細胞がともに関与し, 相互に関連していることを示し ている、そしてこれらの増殖因子の局在は腫場の増殖, 進展に重 要な役割を果たしていることを示唆している。
P-12）モノクロナール抗体とサイトカインの併用 療法一ヒト悪性グリオーマに対する基礎的 研究一

付属病院脳神経外科高橋 弘・山口文雄・草搏博昭 中沢省三

インターフェロン (IFN) や腫湯壊死因子 (TNF) には直接の 抗腫瘍効果に加之, 間接効果があることが知られており, 覀性腫 湯に対するモノクローナル抗体療法の作用機序の増強に有効上 考えられる。今回，われわれはヒト悪性グリオーマに対して強い 結合性を示すヒトモノクローナル抗体 (MAb) CLN-IgGの作用 が，これらサイトカインで増強されるかどらかを娭討した。

ヒト悪性グリオーマ細胞 U-87MGをin vitroでヒトIFN と TNFで処置し，CLN-IgG との結合性をEIA 法で測定した。サイ トカイン処置した細胞は, 未処置細胞よりも高い結合性を示し, この効果はサイトカインの処置量が多いはど大きかった。さら に, U-87MG 皮下移植ヌードマウスモデルを用いて, CLN-IgGの 腫瘍増殖抑制効果における IFN- $\beta$ の併用効果を検討し, その有 効性を確認した。

以上の結果より, IFN- $\beta$ がヒト悪性グリオーマに対するヒト MAb CLN-IgGの腫㳻集積性を増強し，併用効果を持つことが示 された。

\section{P-13）巨細胞神経膠芽腫の 1 例}

付属病院脳神経外科 玉置智規 - 石郷岡聡 - 佐々木光由 小林士郎・中沢省三

神経膠芽腫の中でもきわめてまれな組織型とされる巨細胞神 経膠芽腫の 1 例を経験したので報告する。

症例は 17 歳男性. 昭和 63 年 11 月頃から頭痛, 嘔吐が出現, 近 
医眼科にて眼底に5っ血乳頭を指摘され当科入入院した。 入院時 意識は清明で神释脱落症状は認めなかった，X線 CTおよび MRICT にて左前頭葉に腫瘍が発見され，12月に腫崵摘出術を施 行した。病理組織学的崄断は巨細胞神経膠芽腫であった。術後 60 Gy の放射線照射, VCR, ACNUによる化学療法を行い, 再発の 兆候，所見なとなく退院となった。その後外来経過観察としてい たところ, 平成 2 年 7 月 11 日 CT にて左前頭葉に再発像を認め たため 7 月 19 日再度腫瑒摘出術を行った。病理診断では前回と 同様の巨細胞神経膠芽腫であった。

神経膠芽腫は脑腫場全体の䄪 $7 \%$ を占める最も悪性の脑腫瘍 であり，その平均余命は 8 力月前後といわれる。.巨細胞神経膠芽 腫はその中でもまれな組織型であるが，比較的予後良好な経過を とるものがあるとされ，われわれの症例においても現在まで 22 力月の生存期間を得ている。この巨細胞膠芽腫の症例について電 顕、光顕的病理組織所見を含め, 若干の文献的考察を加兄報告寸 る.

P-14）精神疾患における脳血流シンチグラム上の crossed cerebellar diaschisis 出現について

$\begin{aligned} & \text { 付属病院放射線科 } \text { 水村 直 - 大石卓爾 - 斉藤了一 } \\ & \text { 恩田宗彦・高村修司 - 天野康雄 } \\ & \text { 林 宏光・玉井 仁 - 恵畑欣一 } \\ & \text { 同 神経科 高木宏昌・葉田道雄 - 竹原 恵 }\end{aligned}$

(目的)脳血流シンチグラム上, 精神疾患に扰いて片側小脳半球 の反応性血流低下および代勆機能低下を反映した diaschisis 現 象と思われる変化を生じることがあり，今回臨床的に疾患と同現 象との関連につき若干文献的考察を加え検討した。

(方法)精神疾患 30 例 (13～72 歳)を対照として脳血流 SPECT 像を得, 小脳領域に関し視覚的評価とカウントの定量的評価を対 側との比較形式で行った。

(結果) 視覚的評価から明らかな diaschisis を認める症例は, 分裂病 5 例中 2 例，5つ病 11 例中 2 例であった，立た，定量的評 価でもほぼ同様の結果を得た。

(考察) crossed cerebellar diaschisis は大脳半球に比較的著 明な血管障害を持つ場合に対側の小脳血流低下をきたす現象で， 皮質小脳投射路の関与が考之られているが，機序はいまだ不明な 点が多く，さらに小脳性失調症状を必ずしも伴わなら点で, その 意義についてはいまた確固とした意見がない，今回器質的障害が 又られない精神疾患においても同梯の現象を生じる場合がある ことを脑血流 SPECT imageがく表現し得た点で, 本法はきわ めて有意義であった。 Tc 99 m-HMPAO，あるいは1123-IMP SPECT は他の間接的評価法に比し，より直接的局所的脳代謝評 価法として客観性, 定量性の面において現行の手段としては PETとならび最す優れた方法といわれ，今後さらに不可解な脳 の機能的現象解明に貢献するところ大であると考光る.

\section{P-15）内澒動脈瘤を合併した Persistent primi- tive trigeminal artery $の 1$ 例}

\author{
付属病院脳神経外科 浜田 浩 - 足立好司 - 清水澄江 \\ 池田幸穂・中沢省三
}

Persistent primitive trigeminal artery (PTA) は, 内頸動脈 一脳底動脈吻合遗残のらち最も頻度が高く, 脳血管撮影上 0.1〜0.3\%にみられる。一般的にはPTA 自体が臨床症状を呈す ることは少なく，偶然に脳血管撮影により発見されることが多い といわれている.PTA と脳動脈瘤との合併例については,いくつ かの報告がなされているが，いわゆる脳動脈瘤の好発部位にみら れることが多い，また，巨大動脈瘤との合併については 1 例が報 告されているのみである. 今回, われわれは内頸動脈分岐部 Large aneurysm を合併したPTAの1例を経験したので, 文献 的考察を加光, 報告する。

症例は 65 歳男性で, 意識障害, めまいを主訴に来院. 入院時, 頭部 CT スキャンにて右側脳室に cast 状の脳室内出血, さらに 右側脳室海馬複合体部分で造影剂の増強奻果を認めた。脳血管撮 影では, 右内頸動脈分岐部に径 $15 \mathrm{~mm}$ の large aneurysm 括よび PTA を介する上部脳底動脈の造影が観察された。

PTA などの脳血管の発生過程の異常と, 脳動脈瘤との合併は, 動脈瘤発生の先天的因子説 (中膜欠損), あるいは hemodynamic stress の関与説を支持するものと考えられた。

\section{P-16）初発症状にて真性三叉神経痛が疑われた術 後性煩部哑胞の 1 症例}

\section{多摩永山病院麻酔科 石原之法 - 山田光輝 - 天本治夫 付属病院放射線科細井盛一 神星記念病院 相原康孝}

われわれは，疼痛の初発症状から真性三叉神経痛か症候性のも のか診断の困難な症例を経験したので報告する。

約 20 年前に両側副番腔手術の既応をもつ 38 歳の女性で, 2 日 前よりの突然の左頡関節部から下顎にかけての激痛にて受診す る.

疼痛は間欠的ではあるが圧痛点はなく, 左項部の張りを訴える 他は頓部の腫脹もなく，単純副番腔撮影にても所見はなかった。 鑑別診断として頝椎神経ブロック，星状神経節ブロックを施行す るが除痛できず，真性三叉神経痛の診断にて投与した消炎鎮痛 剤, カルハママゼピンの薬剤も無効であった。 その後, 激痛持続し, さらに頭痛嘔吐出現し, 開口不能となり, CT 検査にて左上䫑洞の 骨破壊像が認められ，上顎癌も疑い緊急手術を施行した。手術所 見は術後性頓部襄胞で軟部組織が充满し mass が後方へと伸展 し，上顎洞後壁 2 力所に骨欠損が認められた。

今回の症例は原因として顔面神経痛, 三文神経痛, 頚椎症, 䫟 関節炎，上䫛洞炎，骨髄炎などが考えられる，炎症所見のない突 発した間欠的な激痛，諸々の鑑別的ブロック，単純撮影所見も異 常なく，真性三叉神経痛と診断した，その後随伴症状が出現し CT

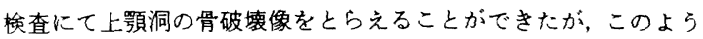
に上顎洞内容物の增大が頓部には及ばず後方へのみ伸展した場 合，三叉神経への王刺激が增大し疼痛のみが顕著な訴えとなるの で，疼痛の鑑別には注意を要する。 


\section{P-17）中耳カルチノイドの 1 例}

\section{第一病院病理部 竹田数章 $\cdot$ 大塚俊司・松本光司 山田宣孝 \\ 同 電䫒室 並松茂樹

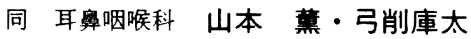

中耳カルチノイドは，非常にまれな疾患であり，過去 20 年間 で, 本邦では 6 例, 世界では 20 例の報告をみるのみである. 今回, われわれは初回の病理診断では, 腺癌の疑いとされ，その後の酵 素抗体法を含む特殊染色捄よび電顕によりカルチノイドと診断 された症例を経験したので報告する。

主訴扣よび現病歴：57 歳の女性. 主訴は右耳閉感，右難聴。初 診時の耳鏡所見では, 右鼓膜は淡赤色を呈し, 軽度膨隆が認めら れ，鼓室内に腫瘤の存在が疑われた。平成元年 10 月 26 日，右鼓 室内腫瘍摘出術, ならびに乳突洞削開術を施行し, 鼓室内の腫瘍 を摘出した。

病理組䅧所見：HE 染色では紡錘形細胞が渦巻状構造を示し て浸潤性増殖を示した部分と上皮様細胞か，索状構造を示して増 殖する部分を認めた。核は小型，円形で異型性に乏しい所見を示 した。特殊染色ではグリメリウス染色陽性，醅素抗体法ではケラ チン陰性一弱陽性, EGC 陽性, 電顕的観察により, 胞体内に神経 分泌顆粒が多数認められ，カルチノイド腫瘍と確定診断された。

本例はきわめてまれな症例であり，特に電顕的観察が診断に有 効であった。

\section{P-18）小腸による気管再建の実験的研究}

\author{
外科第 2 朝戸健夫・秋丸琥甫・吉川 晃 \\ 後藤 学・吉尾 隆・渡辺一彦 \\ 家所良夫・松島伸治・日置正文 \\ 庄司 佑
}

目的：小腸が気管の代用に成り得るか否かを証明するために, イヌを用いて気管再建の実験を行った。

方法: 雑種成犬（体重 $9 \sim 13 \mathrm{~kg}$ ) 8 頭を静脈麻酔下儿上腹部正 中切開し, 灌流後, 小腸を $6 \sim 7 \mathrm{~cm}$ 切除した。腸の吻合, 閉腹 後, 頸部を縦切開し気管を十分に露出し 6 気管軟骨輪を管状切除 した，先の小腸切除片を， $20 \mathrm{~m} l$ のディスポーザブル・シリンジ 外筒で作成した人工軟骨輪の中に捙入し，小腸内腔を確保するた めに, 人工軟骨輪と小腸壁笳層とを外から吸収系を用いて 10 数 箇所を縫合固定し，代用気管グラフトとした。ささらにグラフトは 上下で気管と 3-0 ネスピレンで連続縫合で吻合された。

結果：雑種成犬 8 頭を用いた。麻酔死 3 頭, 術死 1 頭, 残り 4 頭はすぺて 1 カ月以上生存した。この5ち2 例は近位吻合部狭窄 がみられ，ともに1 カ月で屠殺したが，他の 2 例は健在で 2 力月， 6 カ月を経過観察中である.

結語：人工軟骨輪で支えられた小腸グラフトは, 臨床における 気管あるいは気管支の広範な切除後の再建に応用できると思わ れる。

\section{P-19）肺癌細胞株における細胞外基質への接着, 浸 潤能と In vivo 転移能}

呼吸器科酒井茂利・渋谷昌彦・飯塚和弘 馬場 誠・忽滑谷直孝・大塚麻理子 青山昭徳・森川哲行・仁井谷久暢

日本化薬総研 内田智子・浴本久雄

(目的)肺小細胞癌は予後の悪い癌として知られているが，その 原因として早期に転移，浸潤をみることがあげられている，今回 われわれは小細胞肺癌株として H 69，N 231，Lu 135，Lu 143， 非小細胞肺癌株としてPC 7, PC 9, PC 14 を用い, in vitroにて 細胞外基質との接着と Boyden-Chamberを使用したinvasion assayにより, 両者の接着, 浸潤能と type IV collagenase 活性 を検討し，併せて nude mouse による in vivo artifial metastasis の采に打いても比較したので報告する。

（結論）(1) Laminin, type IV collagen, matrigelなどの細 胞外基質において，小細胞癌株の接着能が高く invasion asay, type IV collagenase 活性においても同様の結果が得られた。 た, in vivo artificial metastasisの系において H 69 にのみ肺転 移巣が観察された。 以上より肺小細胞癌が早期に浸潤, 転移をき たすことの一因として, 細胞外基質への高い接着, 浸潤能の関与 が示唆された。

（2）細胞接着部位合成 peptide 低濃度の抗癌剂により, 臨床的 に小細胞肺癌の転移の過程における lodgementを抑制できる可 能性が示唆された。

\section{P-20）非小細胞肺癌に対する術前化学療法の検討}

付属病院チェスト カンフフレンス
グループ呼吸器科

胸部外科 吉森浩三・渋谷昌彦・仁井谷久暢
小泉潔・五味渕誠・塩田晶彦 田中茂夫・庄司佑

付属病院放射線科片山信仁・本多一義・恵畑欣一 病理第 1 川本 雅 司・山中宣昭 坪井病院 長谷川浩一・岩波 洋・坪井栄孝

われわれは非小細胞肺癌を対象に術前術後補助免疫化学療法 による外科治療症例の予後の改善の可能性を㛟討している. 現在 までに術前化学療法の施行された 9 例について化学療法の効果 を検討した。

対象・方法：臨床病期 I IIIA の非小細胞肺癌で, 治瘾切除が 可能と考えられる症例を対象とした。術前化学療法はMVP療法 (MMC $10 \mathrm{mg} /$ body Day $l$, VDS $3 \mathrm{mg} / \mathrm{sq} . \mathrm{m}$ Day $l$, 8, CDDP $80 \mathrm{mg} / \mathrm{sq} \cdot \mathrm{m} \mathrm{Day} l$ ) を1 コース施行後, 効果にかかわらず治复切 除が可能と考えられた症例に外科治療を行った。術後 MVP 療 法, またはMVP 療法にLAK 療法を併用した免疫化学療法を施 行した。

結果：臨床病期 I 期 2 例, II 期 2 例, IIIA 期 6 例, 年齢 37 74 歳 (中央値 63 歳), 組織型は, 腺癌 5 例, 扁平上皮癌 4 例, 大細 胞癌 1 例であった。術前化学療法の効果は PR 1 例, MR 1 例, NC 7 例, NE 1 例, response rate は10\%であった。治切除は 
6 例, 相対的治离切除は 2 例, 非治㟢切除は 2 例に施行した。

さらに臨床的効果判定と組織学的効果判定の相関について㭘 討する予定である。

\section{P-21）胸部 X 線像における CRT 診断について 一肺癌検診例の検討一}

付属病院放射線科 本多一義・片山信仁・赤沼弘勝 水村 直・林 宏光・山本 彰 恵畑欣一

多摩永山病院放射線科 孫田誠二

目的：近年医用画像におけるデジタル化には目をみはるもの があり，名分野においてその有用性に対する報告を散見する、今 回, 従来のフィルム・増感紙系像（アナログ像）による胸部単純 $\mathrm{X}$ 線写真をもとにフィルムデジタイザーを用い,デシタル化(デ シタル像)としCRT 表示による診断を試み,その有用性について 検討した。

方法：都内 A 区の肺癌検診胸部単純写真 215 枚 (例) について TDI S-500に付隨するフィルムデジタイザーを用い，サシプリン グピッチ $200 \mu$ としデジタル化した。デジタル像は走査線 1,650 本の高精細 CRT に表示した，表示方法は 2 台の CRT を用い(1) 従来のアナログ像に近い像，(2)(1)に周波数処理を加元た像，(3)(1) の反転像に周波数処理を加之た像の 3 種類とした。画像の検討は 2 名 1 組としてナロク像 CRT 像を別々に観察した。検討項目は 異常なしを含む 16 項目を設定した。

結果：215 例中アナログ像にて異常を指摘した例は 65 例であ ク,デジル像では 90 例であった。このらち20 例はアナログ像 デシタル像とも同じ異常影を指摘した。フナロタ像にて指摘され デシタル像にて指摘されなかった異常影は胸膜掼着像、リンバ節 石灰化像が多く、デシタル像にて指摘され，アナログ像にて指摘 されなかった異常影は線状影, 索状影が多かった。

\section{P-22）培養ウシ気管支上皮細胞と気管腺細胞に対 する Transforming growth factor type beta の効果}

外科第 1 松田範子・恩田昌彦・笹島耕二 松田 健・渡辺学

Univ. of Nebraska, S.I. Rennard
Med. Ctr.

[目的] Transforming growth factor-beta (TGF- $\beta$ ) は, 正 常上皮細胞の扁平上皮化生を誘導すると報告されている。そこで TGF- $\beta$ の効果をウシ正常気管支上皮細胞 (BBEC) と気管腺細胞 （BTGC）を用い，その増殖と分化について検討した。

〔方法〕BBECは，気管支の小片を $0.1 \%$ protease入りの MEM, $4{ }^{\circ} \mathrm{C}, 12 \mathrm{hr}$ 処理し, 翌日 $10 \% \mathrm{FCS}$ を含む MEM で洗浄, 遠沈後単一細胞とした. BTGCは，気管から粘膜下層を剥がし， それを $0.2 \%$ protease 入りの MEMに $37^{\circ} \mathrm{C}, 1 \mathrm{hr} ., 5 \% \mathrm{CO}_{2}$ イン キュペートし単一細胞を採取した。BBECは初代培養細胞を用 い, BTGCは 10 数代継代培着細胞を用い実験に供した。BBEC は $1 \times 10^{5}$ ，BTGCは $1 \times 10^{4}$ そ $35 \mathrm{~mm}$ の culture dishにをき， $5 \%$ のワマ血清を含むMEM 培地で培着した. $24 \mathrm{hr}$. 後より,そ
れぞれの細胞に対する $100 \mathrm{pM} \mathrm{TGF.} \beta$ の影響を調べた。細胞の 増殖に関しては細胞数を測定し, 分化に関しては形態学的に観察 した.

[結果〕培養 7 日後, BTGC は control で $1.88 \times 10^{4}$ であるのに 対し， 100 pM TGF. $\beta$ では $4.40 \times 10^{5}$ と有意 $(\mathrm{p}<0.001)$ に増加 し，9日目でも同様の傾向を示した。これに比し，BBECは逆に $100 \mathrm{pM}$ TGF- $\beta$ では細胞の増殖が抑制され，細胞数は control の $50 \%$ であり，扁平上皮化生を示した。このよ5に TGF- $\beta$ は同じ 上皮由来の正常細胞に対して，上皮細胞と腺細胞では相反する影 辢を与えた。

\section{P-23）喀血を主訴とした気管支動静脈奇形の 1 例}

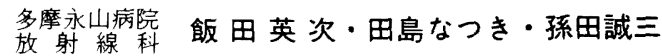

$$
\begin{aligned}
& \text { 山本鼎 } \\
& \text { 同救命救急和田英理・小田彰 } \\
& \text { 同 外科 加藤 俊二・吉 岡 正 智 } \\
& \text { 同 病理部 前田昭太郎 }
\end{aligned}
$$

反復する喀血を主訴とする疾患の中で, 動静脈奇型の占める割 合は少なく、しかもその大部分は肺動静脈奇型である. 今回われ われは，きわめてまれな気管支動静脈奇形の1例を経験したので 報告する、

症例は 66 歳女性で，反復する喀血を主訴とし精査目的にて来 院した、既往歴, 家族歴に特記すべきことはなく，疑固機能を含 めて血液検查所見にも異常を認めなかった。胸部 X線写真, 胸部 断層写真, 㧍よび CT 像では, 左上葉舌区末梢に小腫瘤状陰影を 認めた。また，気管支鏡検査では，左上葉気管支舌区枝起始部に, 径 $5 \mathrm{~mm}$ 程度の暗赤色, 表面やや顆粒状の隆起性病変を認め, き わめて易出血性であり，血管性病变を疑った，次いで気管支動脈 造影を施行したところ, 左気管支動脈舌区枝の払張と, 動脈相早 期における著明に払張した気管支静脈の描出を認め, その起始部 は腫瘤状陰影に一致していた。

以上より気管支動静脈奇形と診断し, 左上葉舌区部分切除術か 施行された。摘出された病理標本では, 動静脈が集簇して認めら れ気管支動脈奇形々確認された。

本症例に打いては気管支鏡のみならず，気管支動脈造影がきわ めて有用であった。これより, 喀血の診断における気管支動脈造 影の有用性が改めて示唆された。

\section{P-24）乳癌の乳房温存療法における放射線治療の 実際}
付属病院放射線科 美濃部かおり・宮下次廣・堀内淳一 小俣香・高橋修司・水村 直 恵畑 欣 -

外科第 1 古 川 清 憲・恩田昌彦

[はじめに]近年, 自己検診の普及により早期乳癌症例が増加し ている、また, 女性の意識の変革もあり, 乳房温存療法の適応が 増加してきた。 われわれが今回経験した乳腺区域切除術十腋窩り ンパ節郭清術の後に行われた放射線治療の実際について報告す 
る.

[対象・方法] 症例は 42 瓷女性，左乳房 CD 領域に腫瘤を自己 触知し、針生検で乳頭腺管癌と診断された。臨床病期は（T1 cNOMO）I 期であった。早期癌のため, 病名を告知した上で informed concentにより乳房温存療法を行らことになった。 quadrantectomy と level I + II の axillary dissectionが行わ れた。術後 3 週間目より $6 \mathrm{MVX}$ 線を用い，術後照射を行った。 照射範囲は残存乳房全体と切除されていない level III の腋窩り ンパ節である，両腕を举上した背臥位で接線方向より $8 \times 18 \mathrm{~cm}$ の照射野を X 線透視位置で決め，装置で皮阑にマーキングした。 次に乳房内の線量均一化のため, コンピュータによる線量計算プ ログラムを利用して最適な wedge filterの選択を行った。総線量 は $50 \mathrm{~Gy} / 25$ 分割/ 5 週間とした。

[結果・考察] 乳房と胸壁の線量分布は満足できるものであっ た。観察期間はまた長くないが，残存乳房は美容上容認できる色 調と形態を示し患者も満足している，今後，緎維化により，触診 がやや困難になることが予想されるが注意深い経過観察を行い たい.

\section{P-25）乳癌の免疫組織学的検討-epidermal growth factor receptor, epidermal growth factor, c-erbB-2 product, estrogen receptor $の$ 染色条件の検討一}

$\begin{aligned} \text { 老人病研究所 } & \text { 片山博徳 - 小山美弥・大網 弘 } \\ \text { 東京女子医科大学 福内 敦 - 监玉孝也 } & \end{aligned}$

目的：乳癌細胞において, estrogen receptor (ER) や epidermal growth factor (EGF) と, epidermal growth factor receptor (EGFR)，また EGFRをコードするc-erbB-2(erb-2B)のモノク ロナール抗体を用い，その相互関保を検索するために免疫染色法 の条件を検討した。

材料および方法：原発性乳癌初回手術組織 39 例, 全例女性. 年 齢は 25 76 歳平均年齢 53 歳を対象とした。染色条件の検討には 畽膓組織が十分量あるもの 10 例を用いた。畽煬組織は摘出後直 ちに 5 分割（厚さ $2 \mathrm{~mm}$ 以下）し，各々. 1. PLP 固定凍結, 2. PLP 固定バラフィン包埋, 3. 10\%ホルマリン固定バラフィン包 埋, 4. AMEX 法, 5. 未固定凍結などで処理した。 未固定凍結し た組織の固定は風乾後 $4 \%$ バラホルムアルデヒド，冷アセトンを 用いた。染色法は， $\mathrm{ABC}$ 法を用い，標識酵素はアルカリフォス ファターゼ (Al-P) とペルオキシダーセ（Po）とした。 また，発 色基質, 凍結切片作製時のスライドガラス塗布試薬, 内因性酵素 活性阻止法, 2 重染色法についても検討し, PLP 固定凍結切片に よる免疫電顕も行った。

結果：未固定凍結切片ー $4 \%$ バラホルムアルデヒド固定, PLP 固定凍結切片で再現性のある結果を得た。免疫電顕においては細 胞膜に一致して抗原の局在が観察された. ER と EGFRは負の相 関関俰が認められた。 また，EGFR 陰性、リンバ節転移のある 3 例中 2 例において erbB-2 の陽性所見を得た.
P-26）乳癌のレセプター検索における生化学的方 法と免疫組織化学的検索との諸問題の検討

\author{
第一病院病理部 大塚俊司・早澤久美・仲原昌子 \\ 中川敬夫・佐藤春明・松本光司 \\ 山田宣孝
}

目的：ホルモン依存性腫瘍である乳癌では，そのエストロゲン レセプター(以下 ER) とプロゲステロンレセプター（以下 PgR) の有無が内分泌㞠法の選択, 予後に深く関与しており, 臨床上, 重要である。この ER, PgR は通常, 生化学による DCC 法で検索 されている，この方法は腫瘍が小さい場合，検索不可能なことが 多く，また検索された組織に癌が含まれないこともある。われわ れはDCC 法だけによる，ER，PgRの検索の矛盾点などについて 検討したところ若干の知見を得たので報告する.

材料拉よび方法：当施設の乳癌で DCC 法にて ER, PgR の検 索がなされた材料を用いて，手術標本より涷結切片を作り，癌組 織であることを確認した後で ER および PgR を免疫組織学的染 色により検索した。 また，通常の方法でホルマリン固定後，パラ フィン包埋した材料でも $\mathrm{ER}, \mathrm{PgR}$ の検索が可能であることも合 わせて検討した。

結果および考察：DCC 法と凍結切片の免疫組織化学的染色に よる ER，PgRは一致した結果を得た。市，バラフィン切片に よるER, PgRの検索はDNaseおよびトリプシン処理により良 好な結果を得た。 また，乳癌に批ける $\mathrm{ER}, \mathrm{PgR}$ の検索は, DCC 法たけでなく癌組織であることを確認しらる利点のある凍結切 片およびバラフィン切片での検索が不可欠と思われた.

以上の成果をいかすために外科との密接な連絡のもとに検索 することが必要と考える。

\section{P-27）MRIによる乳房疾患の画像診断（I）}

\section{第一病院放射線科 佐藤太志・五十嵐義晃 - 伊藤 正 横倉稔明・茂古沼吉宗・赤石 健 石王道人・川勝樹夫・鈴木秀徳 鴨下 烹・青山俊也・加藤富三 外科第 2 馬越正通 $\cdot$ 大場 英己}

目的：最新の画像診断装置である MRIによる乳房疾患への応 用とその画像評価について。

方法） $0.2 \mathrm{~T}$ 永久磁石方式 MRI 装置(日立製) 使用，特製表面 コイル使用， 3 方向撮影，グラディェントェコー法(FA 30。9 $\left.90^{\circ}\right)$ 採用。

対象：乳癌 5 例, 良性疾患 2 例.

結果：乳癌症例 5 例中 4 例は腫瘤を描出できたが $2 \mathrm{~cm}$ を越え ていた１例は呼吸性移動が強く描出しえたのは 3 この病変中 1 コのみであった。

良性腫瘍も描出可能であり，の5腫と線維線腫の鑑別は $\mathrm{T}_{1} \mathrm{WI}$ と $\mathrm{T}_{2} \mathrm{WI}$ にて容易であった。

考察：乳房疾患の画像診断はすでに確立された感のあるX 線 マンモグラフィ，超音波，サーモグラフなどがあるが，そ机らに おいてもな打画像診断上詳細な点において鑑別に困難さを認め ることが少なくない，MRIはその応用において活発とはいえず， それは小病変, とくに石灰化のみを有するよらな病変の描出は不 
適である.MRIの欠点がそこにある。

われわれも症例数が少ないので何ともいえないが，設定条件の 改善，表面コイルの改良など技術的に検討すべき点もあり，今後 の検討課題を多く有する検査方法であると考える.

\section{P-28）乳腺粘液癌の形態学的特徵一非浸潤巣と初 期浸潤巣について一}

\section{長野県かが病理 宮島道博・丸山雄造・土屋䢐一 病理第 2 浅野伍朗}

乳腺粘液癌は乳癌取り扱い規刋では特殊型に属し，その発生頻 度は約 $8 \%$ 前後といわれている。乳癌は非浸潤癌と浸潤癌の $2 つ$ に大別されるが，この粘液癌は取り扱い規約では浸潤癌に分類さ れている、しかし，乳癌はすべて乳管上皮から発生してくること から，粘液癌にもいわゆる非浸潤癌としての時期があるはずであ る、今回われわれは粘液癌の非浸潤巣とそれに続く初期浸潤巣の 形態学的特徵を、微細形態学的, 粘液組織学的に検索したので報 告する.

検索材料は純粋型粘液癌 24 例で，電顕的には $2.5 \% \mathrm{GA} ・ 2 \%$ $\mathrm{OsO}_{4}$ で固定後, 型のごとく脱水包埋し, 透過型電顕にて観察し た。粘液組織学的にはAB-PAS, HID 染色を施行した。

光顕的には, 24 例中 9 例の粘液癌に非浸潤巣がみとめられた。 非浸潤笨は癌巣の辺縁部に多くみられ，その形態は乳頭腺管癌の 篩状型に類似していたが，管腔内には多量の粘液が存在してい た。非浸潤巣の近傍にはしばしば基底膜を破壊して間質に粘液を 放出する極く初期の浸潤巣もみられた。粘液組織学的には，ABPAS は主に細胞外の粘液に陽性を示したが，細胞内はほとんど 染色されなかった，HID は全症例の $25 \%$ に染まり，他の乳癌と比 べて優位に高かった。微細形態学的には，非浸潤巣は笳上皮細胞 と基底板によって曲まれており，その管腔には多量の粘液がるら れたが，癌細胞内にははとんど粘液顆粒は認められなかった。こ の非浸潤巣から浸潤を開始する様式には，基底板の一部を癌細胞 が破壊して，そこから間質に癌細胞と粘液が流出して浸潤するタ イプと, 癌細胞が一斉峰起的に基底板を破壊して周囲に粘液とと もに浸潤するタイプがあり，その浸潤形態にも2 種類あることが わかった。

\section{P-29）心疾患におけるCK-MB 蛋白量の統計学的 手法を用いた有用性の検討}

付属病院中央検査部佐藤寛之・藤井克彦・本山三生 皆川彰

集中治療室 島井新一郎・高野照夫

目的：CK-MBは心哚組織に多く存在し，その活性值は心㬳梗 塞のモニタリングとして重要視されている，免废阻害法による活 性測定法は, 迅速性に優れているが CK-BB，マクロ CKなどの含 有試料では正確性に問題がある。今回, 蛋白量としての CK-MB を測定し心疾患に扮ける CK-MBの有用性を統計学的手法を用 い検討したので報告する。

対象：心筋梗塞 23 例, 狭心症 10 例, 心臓手術 6 例を対象とした。

方法：CK-MB 蛋白量：ケミルミ CK-MBキット (ciba corn. ing), $\mathrm{CK} \cdot \mathrm{CK}-\mathrm{MB}$ 活性值：メルクオート CKおよびメルクオー
ト CK-MB 免疫阻害法（cica merck）を使用した。

結果：発作直後より経時的にCK-MB 蛋白量を测定し，その経 過をみた。萠梗塞患者の場合 $\mathrm{CK}$ およびCK-MB 活性値とほほ 同様に CK-MB 蛋白量は上䄯し，発作後 5〜10 時間でピークと なる。その後下降するが活性値より明らかに早期に正常域に達す る。狭心症患者では $\mathrm{CK}$ および $\mathrm{CK}-\mathrm{MB}$ 活性值は多少の増減が認 められるが，CK-MB 蛋白量はほとんど変化が認められない。

考察・去とめ：CK-MB 蛋白量は活性值とほぼ同様な変動を示 寸が, 活性值に比べ変動幅が少ないうえ消退速度が速く，心㬳梗 塞患者のモニタリングに有用と思われる。 また，狭心症患者では ほとんど上畀することはなく，心脇梗塞との鑑別マーカーとなり 得るであろら。

\section{P-30）陳旧性心筋梗塞患者における無症候性虚血 発作の特徴}

\section{内科第 1 福間長知・岸田 浩・多田祐美子 哲翁弥生・山崎佳子・斉藤勉 早川弘一・奥村英正}

心筋梗塞患者に出現する一過性心筋虚血発作は, 梗塞の既往の ない冠動脈疾患例と比べ，無症候性発作の頻度が高いといわれて いる. その機序については, 梗塞巣に基つくく anginal warning system の障害などがあげられてはいるがいまだ定説はない．わ れわれは，梗塞後の無症候性虚血発作の成因を明らかにするため に，各種臨床的因子について検討した。

[対象および方法]対象は発症後 6 力月以上経過し, 24 時間ホル タ一心電図検査にて虚血性 ST 变化を認めた。陳旧性心脇梗塞患 者 23 例 (60土8 歳). 虚血発作時の胸痛の有無により有症性発作 群 (AP 群) 14 例と無症候性発作群 (SMI 群) 9 例に分類し, 比 較娭討した。

〔結果〕(1) 梗塞領域は, SMI 群が AP 群に比し下壁梗塞が高頻 度であったが, 年齢, 性, DM 合併, 冠動脈障害枝数, 左室分画 駆出率は, 両群間に差なし。（2）発作時最大 ST 下降度, ST 下降 持続時間は, AP 群が SMI 群に比し高值.（3）性格試験（MPI） は, SMI 群が AP 群に比し外交性の傾向が強い（4）知覚闘値は SMI 群が AP 群に比し高値であったが, 神経伝達速度は両群間に 差なし。

〔結語〕以上より, 梗塞後の無症候性虚血発作には, 様々の因子 が関与していることが示焧された。

\section{P-31）日中に発作出現を呈する異型狭心症の臨床 像とその特徵}

内科第 1 多田祐美子・斉藤 勉 - 岸田 浩 哲枌弥生・山崎佳子・福間長知 安 武 正弘・早川弘一・奥村英正

目的：日中に出現する異型狭心症発作の病態生理を明らかに するために臨床背景, Holter 心電图および冠動脈所見を夜間発 作出現例のそれと対比した.

対象と方法）異型狭心症患者 36 例を夜間就寝時にのみ発作か： 出現する $\mathrm{A}$ 群 12 例（52 18 歳）と, 夜間および日中安静または 軽労作にて発作が出現するB 群 24 例 (55 510 歳)の 2 群に分類. 
結果：1) Holter心電図所見: 有症候性発作はA 群 24 回 $62 \%$, B 群 62 回 31\%と B 群で有意に少なかった $(\mathrm{p}<0.05)$. ST 上年開始直前の心拍数は同等だったか，発作時最大心拍数は $76 \pm$ $16 /$ 分に対し， $70 \pm 16 /$ 分と A 群で有意に增加した $(p<0.05)$. A 群の夜間安静臥床時のフーリエ解析を用いた RR 間隔変動の周 波数分析を行った結果，低周波成分（交感および副交感神経系が 関与）はST 上昇発作前に増加する傾向を示したが，高周波成分 (副交感神経系が関与) は不変傾向であった，2）冠動脈造影所 見：有意器質的狭窄例は A 群 $36 \%$, B 群 $64 \%$ と B 群に多かっ た.3）臨床背景：治療成績では Ca 捛抗薬低抗例が $\mathrm{A}$ 群 1 例, B 群 3 例，心事故発生例はB 群にのみ 5 例出現。心電図にて Multispasm と判断された症例はA 群 2 例 17\%，B 群 9 例 $38 \%$ とB群に多かった。

総括：日中に出現する異型狭心症発作は夜間のみに出現する 発作に比し, 無症状, かつ冠動脈病変が重症で治療抵抗例が多く, Multispasmの関与が示唆された. RR 間隔の周波数分析は本症 の成因を検討する上で有用であった。

\section{P-32）日本医科大学第 1 内科における経皮的冠動 脈形成術（PTCA）の初期成績}

内科第 1 佐藤直樹・安 武 正 弘・藤岡幹雄 草間芳樹・佐々木美典・酒井俊太 浅井邦也・鈴木郁代・内田高浩 宗像一雄・岸田浩・早川弘一 奥村英正

集中治療室 今泉孝敬・富田 喜 文・中込明裕 高野照夫

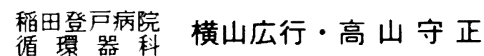

国立横須賀病院 畑 典武・国見聡宏

目的：第 1 内科に㧍ける経皮的冠動脈形成術 (PTCA) の初期 5 年間の成績につき検討した。

方法：対象は 1985 年 12 月 90 年 7 月までにPTCA を施行し 得た 102 例 (男 84 例, 女 18 例, 平均年齡 $58 \pm 9$ 歳)で, 延人数 112 例, 標的部位 123 枝であった. PTCA は全例ジッドキンス法 にて行い, 6 力月後に再狭窄を評価するための冠動脈造影を施行 した. 成功率, 再狭窄率は以下の定義にしたが、評価した。成功： 抬張率 $20 \%$ 以下か抾張後の狭窄度か５0\%以下，再狭窄：狭窄度 の 30\%以上の進行，または得られた径が $50 \%$ 以上進行した場合 か、50\%以下に扗張した病変が $50 \%$ 以上に進行した場合いずれ か.

結果：症例の内訳は, 急性心筋梗塞 20 例, 狭心症 92 例であっ た。標的部位は, 右冠動脈 24 部位, 左前下行枝 74 部位, 左回施 枝 25 部位であり，その狭窄度は完全閉塞 21 例，99\%24 例，95\% 8 例, $90 \% 63$ 例, $75 \% 7$ 例であった。成功率は 123 病変中 104 部 位 $(84.6 \%)$, 再狭窄率はfollow-up 得た 49 病変中 19 部位 (41.3\%) であった。合併症は112 例中 2 例 $(1.8 \%)$ であり，心 筇梗塞 1 例, 急性冠閉塞による死亡 1 例であった。

結語：これまで報告された PTCA の成績は, 成功率 $75 \sim 90 \%$, 再狭窄率 $25 \sim 40 \%$, 合併症 $0.5 \sim 3 \%$ でり, 当科の成績も初期 成樍としては良好な成績であると考えられた。しかし，再狭窄， 合併症が少なからず存在し, これらの予防が今後の検討課題であ ると思われる。

\section{P-33）結節性硬化症の難治性痙繁に対する ACTH 療法中に心臓内腫瘍の増大を認めた 1 例}

\author{
付属病院小児科 小松㟝英樹・深澤隆治・勝部康弘 \\ 日野佳昭・小川俊一・藤野 修 \\ 平山恒夫 \\ 第二病院小巟科橋本 清
}

難治性てんかんに施行される ACTH 㞠法で、しばしば心荕の 肥厚がみられ，心機能の变化をきたすことが知られている。しか し,これまでに心臓内畽瘍に対する影響についての報告はない。

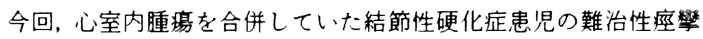
に対して, ACTH 療法を施行したところ, 畽瘍の増大を認め, 心 不全をきたした1例を経験したので報告する。

症例は 1 歳 4 力月女児 (ACTH 療法時). 生下時上り皮席の白 斑と心雑音があり，心ェコーにて右心室内の巨大腫瘍を認め, 生 挨にて横紋筋腫と考えた。生後 3 力月半頃より、ミオク口二-発 作が出現し, 頭部 CT で脳室周囲の石灰化をみた。痤㢣発作は各 種治療に反応せず, シリーズ形成もみられ，脂波では後頭部優位 に, あるいは全般性に不規則な鋭波, むしくは棘波の群発を認め たため, ACTH 療法を開始した。

$\mathrm{ACTH}$ 療法により, 発作は消失し脳波上も改善したが,心土 コ一上, 心室壁の肥厚と畽瘍の増大が進行し, 第 7 週目には心不 全症状が出現したため, ACTHを中止した。

ACTH 中止後, 腫場は次第に縮小し, 約 5 力月後に治療前の大 きさに戻った。

心喴内に腫埸性病変を伴ら例に対して ACTH 療法を行5際に は, その組織型によっては増大し，とくに発生部位が流出・入路 では心不全をきたす可能性があるので,心ェコーによる慎重な監 視・評価が必要である.

P-34）狭心症, 僧帽弁狭窄, 糖尿病, 甲状腺機能低 下症にてコントロールに苦慮した 1 症例

内科第 2 駒場祐一・尾上敏夫・村松 忠 森島明・小林陽二・福生吉裕 赫 彰郎

われわれは，狭心症，僧帽弁狭窄症，甲状腺機能低下症，榶尿 病を有する患者を経験し、コントロールに苦慮したため報告す る. 患者は, 昭和 63 年 1 月入院時, 72 歳の女性. 昭和 59 年他院 にて心不全, 橋本病, 胆石症にて入院. 昭和 62 年には狭心症, 僧 帽弁狭窄症を指摘され入院している. 以後同院にて外来通院とな る. 同年 11 月上旬, 上気道炎に心不全を併発, 同院入院. 急性症 状がある程度改善した後, 甲状腺剤を増量したところ, 狭心症を 頻発し，甲状腺剂中止，血棓をインスリン投与にてコントロール したが不良であった。昭和 63 年 1 月 11 日同院より当科に転院し た. 甲状腺機能低下症について levothyroxin $0.025 \mathrm{mg}$ を開始, $0.075 \mathrm{mg}$ まで漸増していったが, それにつれ安静時狭心症の頻

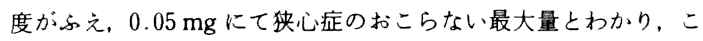
の量で投与したが依然として甲状腺機能低下症のままであった。

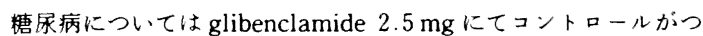
いた. 平成元年 8 月再コントロールのため入院. 入院時高脂血症 も恋めたが, metoprolol $120 \mathrm{mg}$ を用い狭心症を予防しつつ 
levothyroxin $0.125 \mathrm{mg}$ 索堌し狭心症, 甲状腺機能低下症, 高脂血症にある程度コントロールをらけることができた。平成 2 年 1 月末より metoprolol 投与のためか心不全をおこし，2月入 院. metoprolol $40 \mathrm{mg}$, levothyroxin $0.075 \mathrm{mg}$ にてコントロー ルすることを余儀なくされた。

\section{P-35）Verapamil 著効の特発性持続性心室頻拍の 1 例}

稲田登戸病院循環器科 山﨑佳子・洪 基哲 - 内田拓実 横山広行・高山守正・藤原忠通 内科第 1 早川弘一

症例：28 歳男. 主訴：動悸. 既往歴, 家族歴には特記すべきこ となし. 平成 2 年 1 月 11 日早朝に動悸が出現し, 同日昼に当科外 来を受診. 血殴は触診で最高血圧 $100 \mathrm{mmHg}$, 胸部ラ音・心雑音 聴取せず，頸静脈怒張なし。心電図では心拍数 $200 /$ 分でRR 間隔 は規則正しく，QRS 波は右脚ブロックおよび左軸偏位を呈した。 食道誘䢙にて, 心房拍数 120 /分，心室拍数 190 /分の房室解離を認 めたことから持続性心室頻拍と骖断した. lidocaine おょひ disopyramideの静注により頻拍は停止せず, DC shockにて正常 洞調律に復帰した。

胸部 X 線は心胸郭比 $36.3 \%$ で肺野に異常なし。心葴超音波娭 査, 運動負荷試験ならびに冠動脈造影に異常所見を認めず, 明ら かな基礎心疾患の存在は否定され，特発性持続性心室頻拍々診断 した。電気生理学的検査では, 右室心尖部頻回刺激にて臨床的心 室頻拍と同一のQRS 波形を呈する持続性心室頻拍か再現性を もって誘発され，右室頻回刺激にて停止可能であった。誘発され た心室頻拍は verapamil 静注にて洞調律に復㷌し,さらに静注後 は心室頻拍は誘発されなかった，同時に施行した pace-mapping にて心室頻拍発生部位は左室心尖部の後下壁と考えられた。

近年 verapamil が著効を示す右脚ブロックおよび左軸偏位の QRS 波を呈する特発性持続性心室頻拍が注目されているが，本 例はその 1 例と考えられた。

\section{P-36）回転デジタル血管撮影装置を用いた解離性 大動脈瘤における交通口の観察}

\author{
付属病院放射線科弦間和仁・田島廣之・高橋修司 \\ 小俣 香・林 宏光・大石卓爾 \\ 玉井 仁・斉藤了一・宮下次廣 \\ 隈崎達夫・堀内淳一・恵畑欣一
}

(目的)解離性大動脈瘤は複雑な病像を呈するため, その診断に 際してはいまだいくつかの問題点が残されている。なかでも，交 通口の証明は，特に外科的治療を行ら際にきわめて重要である が，画像診断技術の発達した現在においてもなおその診断に苦虑 することは少なくない，今回われわれは，回転デジタル血管撮影 装置を用いて解離性大動脈瘤を観察したところ，従来の血管撮影 と比較して明らかに優れた点が認められたので報告する。

(対象・方法) 対象は 6 例 (男性 4 例, 女性 2 例. 28 55 歳)で, 胸部, 腹部, 骨盤部につき回転デジタル立体血管撮影を行った。 装置は, 回転 X 線テレビ装置(島津)に、新たに作製したデジタ ル画像処理装置を組み込んだものである。
(結果・考察) 病型は，stanford A 群 4 例，B 群 2 例であった。 手術が行われた症例では，確認し得た交通孔はすへて術前診断と 一致した。本法は, 従来の血管撮影法と比較して交通口の部位診 断が容易に行えたが, これは多方向からの動画像が連秸的に得ら れるため, 交通口の位置を示す jet を最適の角度から観察し易い ためである，以上より，本法は，解離性大動脈瘤に拈ける交通口 の診断にきわめて有用であることが明らかとなった。

\section{P-37）経皮的下大静脈フィルター留置の経験}

付属病院放射線科田島廣之・隈崎達夫・伊藤公一郎 弦間和仁・大矢 徹・恩田宗彦 赤沼弘勝・斉藤了一・山本彰 恵畑欣一

下肢, 骨盤静脈血栓症は, しばしば肺血栓塞栓症をびきおこし, ときに重篤な転慢をとる。この再発を予防する方法として, 従来 下大静脈結禁術や外科的下大静脈フィルタ一插入術が行われて きたが，その手技は煩雑でときに合併症もみとめられる．今回わ れわれは，七ルジンガー法にて経皮的に挿入可能な下大静脈フィ ルターを使用する機会を得たので報告する.

対象は下肢深部静脈血栓症に起因する肺血栓塞栓症々䛦断さ れた 2 例で，いずれも女性，年齢は 53 歳と70歳であった。1例 では経過中に肺血栓塞栓症の再発がみられ，また，1例では下肢 深部静脈血栓症の改善が得られなかったため, 肺血栓塞栓症の再 発予防の目的で下大静脈フィルターを插入した。

使用したフィルターは, 直径 $22 \mathrm{~mm}$ の Günter 下大静脈フィル ター (cook) で, 大眼静脈経由にて, 腎静脈より尾側の下大静脈 まで挿入・留意した，手技はきわめて容易で，明らかな合併症は 認められなかった。今後症例を重ねるとともに，長期にわたる経 過観察を行いたい.

\section{$\mathrm{P}-38 ）$ 微小食道癌症例の検討}

外科第 1 山下精彦・恩田 昌 彦・笹島耕二 田尻孝・中島米次郎・松倉則夫 京野昭二・有馬保 正・鈴木英之 池田五十鈴・美濃部かおり 田久保海誉

$\begin{array}{ccc}\text { 付属病院 } & \text { 平良晋一・奥 田 稔 } \\ \text { 内科第 } 3 & \text { 小林正文・野 村 武 夫 }\end{array}$

目的：食道癌は他の消化器癌のなかで最も予後不良の一つで, 早期癌が発見されにくく進行癌が多いことにもよる. 当教室で過 去 16 年間の 264 症例中, 切除は 159 例, 切除率 $60.2 \%$, 早期癌は $\mathrm{sm} 8$ 例, $\mathrm{mm} 3$ 例, ep 1 例の 12 例, 7.5\%にすぎない. その5 ち $1.0 \mathrm{~cm}$ 以下の微小癌は 3 例あり検討した。

症例 $1: 61$ 歳, 男性, 主訴は下咽頭痛, 左上頝部腫瘤の下咽頭 癌, 精査で食道癌, 胃癌が発見され同時性三重複癌であった。 下 咽頭癌は $\mathrm{T}_{2} \mathrm{~N}_{1} \mathrm{M}_{0}$ の stage III, 高分化型扁平上皮癌, 食道癌は $\mathrm{Ea}, 0.5 \times 0.5 \mathrm{~cm}, \mathrm{O}-\mathrm{II} \mathrm{a}, \mathrm{mm}$, 低分化型扁平上皮癌, 胃癌は $3.0 \times$ $4.0 \mathrm{~cm}$, IIc, m, signet ring cell carcinoma であった.

症例 $2: 63$ 歳, 男性, 主訴は㖟下時のシミル感じ, 健診で胃潰 
湯軗痕指摘, 内視鏡娭査で食道の Iuに発赤, ルゴール染色で不 染, 生検で扁平上皮癌, Iu, $0.7 \times 1.0 \mathrm{~cm}, \mathrm{O}-\mathrm{II}, \mathrm{ep}, \mathrm{Squamous}$ cell carcinoma in situであった。

症例 $3: 69$ 歳, 女性, 主訴は胃部不快感, 内視鏡検査で食道胃接 合部直上に浅い陥凹, ルゴール染色にて不梁, 生検で扁平上皮癌, $\mathrm{Ea}, 0.6 \times 0.8 \mathrm{~cm}, \mathrm{O}-\mathrm{II} \mathrm{b}, \mathrm{mm}$, 中分化型扁平上皮癌であった。

結論：食道癌の手術成績向上のためには, 早期癌を発見するこ とであり，他の癌の症例にも重複癌を念頭におくこと、ルーチン の内視鏡検査でも発赤, 小隆起, 小陥凹には積極的に色素散布 (儿 ゴール染色）することが有効な手段である.

\section{P-39）ヒト胃癌における c-erbB-2 の発現}

\begin{tabular}{|c|c|}
\hline \multirow[t]{4}{*}{ 外科第 1} & 水谷 崇・恩田昌彦・木山輝郎 \\
\hline & 奥田武志・吉行俊郎・清水康仁 \\
\hline & 西＼cjkstart恵吾・松倉則夫・田中宣目 \\
\hline & $\begin{array}{l}\text { 山下精彦・徳永 昭 } \\
\text { 山中宣昭 }\end{array}$ \\
\hline
\end{tabular}

病理第 2 浅野伍朗

c-erbB-2 遗伝子は，EGF-receptor と相同性をもち，ヒト腺癌 において増幅が特異的にみられると報告されている，そこで当教 室における胃癌切除症例に対し, c-erbB.2 の発現を免疫組織化学 的に観察した。

[対象および方法]胃癌切除症例 185 例のホルマリン固定バラ フィン切片について抗 c-erbB-2ポリクロナール抗体（Triton 社 製)を用い $\mathrm{ABC}$ 法にて免疫染色を行い, MKN-7 胃癌培盖細胞を 陽性対象としてその発現を判定した。

〔結果〕 c-erbB-2 陽性率は23/185（12.4\%）で，陽性例におけ る染色性の局在は, 主として腫煬細胞膜および細胞質に認められ た.5ち早期癌では 6/88 (6.8\%), 進行癌で 17/97 (17.5\%) と 進行癌で有意に高率であった $(\mathrm{p}<0.05)$. 組織型は intestinal type $15 / 90(16.7 \%)$, diffuse type $8 / 95(8.4 \%)$, 間質は scirrhous type $5 / 45(11.1 \%)$, non-scirrhous type $11 / 52(21.1 \%)$, また $\mathrm{n}(+) 13 / 83(15.7 \%), \mathrm{n}(-) 8 / 97(8.2 \%), \mathrm{ps}(+) 14 / 81(17.9 \%)$, ps (-) 9/104 (8.6\%) であった. c-erbB-2 の発現と stage およ び生存率に関しては明らかな関連は認められなかった。

〔まとめ〕ヒト胃癌における c-erbB-2 の発現は，早期癌に比べ 進行癌に有意に高率に認められ，またintestinal type, non scirrhous type, n (+), ps（十）により高率にみられる㑯向が あった。以上よりヒト胃癌とくに分化型腺癌の分化・増殖に c-erbB-2 が関与し, その発現が腫瘍の悪性度の指標となる可能性 が推測された。

\section{P-40）ヒト胃癌におけるへパリン結合性増殖因子 群の発現の解析}

外科第 1 飯田信也 恩田昌彦・山下精彦 田中宣威・徳永 昭・笹島耕二 松倉則夫・水谷 崇

国立がんセンター 研究所分子腫境学部
（目的）国立がんセンタ一研究所分子腫演学部において，手術 時摘出胃癌のDNAよりトランスフォーミング遗伝子として HST 1 遺卮子が分離・同定された。その遗伝子産物は，酸性打よ び塩基性線維芽細胞增殖因子 (a, b FGF), INT 2・FGF $5 \cdot$ hst2 の各遗伝子産物, KGF の 6 種類の蛋白質と相同性を有し，いわ ゆるへパリン結合性増殖因子 (HBGF) 群を形成している。これ はHBGFならびに HBGF 受容体と胃癌との関連について検討 した。

(方法) ヒト胃癌培養細胞株 9 種および手術時摘出胃癌組織数 例よりトータル RNA，あるいはポリ $(\mathrm{A})+\mathrm{RNA}$ を抽出し，－ ザン・ブロット法,さらにはより感度の高い CDNA-PCR 法を用 いて，胃癌に扮ける HBGF 群各因子と一部の HBGF 受容体の mRNA の発現を解析した。

（結果）ノーザン・ブロット法を用いた場合，ヒト胃癌培養細胞 株 9 種中 2 種において bFGFの mRNAの発現が認められ, また 手術時摘出胃癌組織においてもbFGFの mRNAの発現がみら れた。一方，国立がんセンタ一分子腫煬学部において分離・同定 された N-sam（bFGF 受容体）遺伝子についても同様に検討し， 胃癌細胞株 9 種中 3 種にその mRNAの発現が認められた。さら に, 発現が微弱でノーザン・ブロット法では検出し得ない場合で も, cDNA-PCR 法を用いることにより, 発現を検出し得た例が存 在した.

以上より，ヒト胃癌の発生または進展に HBGFが関連してい る可能性が示唆された。

\section{P-41）当内視鏡科における胃ポリープの最近の趨 勢}

内視鏡科 重田明子・山口和彦・大島 博

近年, 集団検診や老人健診の普及により多くの胃ポリープが発 見されるよらになった。当科で内視鏡的に胃ポリープと初診した 症例について，最近の赹勢を検討した，

(対象) 当科に执いて 1985 年 1 月 89 年 12 月までの 5 年間に 内視鏡的に胃ポリープと診断した 519 例，859 個を対象とした。

（成績）1）胃ポリープの増加：当科に损ける1977年〜81 年ま での 5 年間に診断した胃ポリープは 184 例, 315 個に過ぎない.今 回集計した 5 年間では各々 3 倍に近い増加を示した。2）年齢別 頻度：胃ポリープ患者の数は, 50 歳代までは年齢の増加とともに 増之，50歳代で $30.4 \%$ と最も高い頻度を示す，3）性比：胃ポ リープ患者の男女比は, 男性 288 例に対し女性 231 例, 寸なわち $1.2 ： 1$ 上近似している.4）単, 多発：全例において単発 $68.6 \%$, 多発 $31.4 \%$ であった，5）肉眼型別：胃ポリーブを山田分類によ り比較すると, 859 病変中 I 型 $13.0 \%$, II 型 $63.0 \%$, III型 $11.3 \%$, IV型 $12.7 \%$ とII 型が最も多い．6）大きさ：ポリープ頭部の大き さを内視鏡診断に基づき分類すると， $5 \sim 9 \mathrm{~mm}$ が $74.9 \%$ と最も

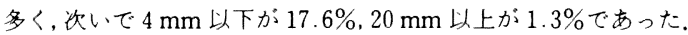
7) 占居部位：胃ポリーブ 859 病変を胃癌取り扱い規約にした がって分けると，A 領域は $47.1 \%$ と最も多く， M 領域 $32.1 \%$, C 領域 $20.8 \%$ の順で，大弯 $35.8 \%$ ，前壁 $25.5 \%$ ，後壁 $21.2 \%$, 小弯 $17.5 \%$ であった. 8 ）病理組織型：ポリペクトミー,あるいは 生検によって病理組織型の明らかな207例については hyper plastic polyp が $89.4 \%$, metaplastic polypが $10.6 \%$ と前者が 圧倒的に多い. 